\title{
Effects of pathogen-specific clinical mastitis on probability of conception in Holstein dairy cows
}

\author{
J. A. Hertl, ${ }^{* 1}$ Y. H. Schukken,† F. L. Welcome, ${ }^{*}$ L. W. Tauer, $\ddagger$ and Y. T. Gröhn* \\ *Department of Population Medicine and Diagnostic Sciences, College of Veterinary Medicine, Cornell University, Ithaca, NY 14853 \\ †GD Animal Health, 7400 AA Deventer, the Netherlands \\ ¥Charles H. Dyson School of Applied Economics and Management, College of Agriculture and Life Sciences, Cornell University, Ithaca, NY 14853
}

\section{ABSTRACT}

The objective of this study was to estimate the effects of pathogen-specific clinical mastitis (CM), occurring in different weekly intervals before or after artificial insemination (AI), on the probability of conception in Holstein cows. Clinical mastitis occurring in weekly intervals from 6 wk before until 6 wk after AI was modeled. The first $4 \mathrm{AI}$ in a cow's lactation were included. The following categories of pathogens were studied: Streptococcus spp. (comprising Streptococcus dysgalactiae, Streptococcus uberis, and other Streptococcus spp.); Staphylococcus aureus; coagulase-negative staphylococci (CNS); Escherichia coli; Klebsiella spp.; cases with CM signs but no bacterial growth (above the level that can be detected from our microbiological procedures) observed in the culture sample and cases with contamination ( $\geq 3$ pathogens in the sample); and other pathogens [including Citrobacter, yeasts, Trueperella pyogenes, gram-negative bacilli (i.e., gramnegative organisms other than E. coli, Klebsiella spp., Enterobacter, and Citrobacter), Corynebacterium bovis, Corynebacterium spp., Pasteurella, Enterococcus, Pseudomonas, Mycoplasma, Prototheca, and others]. Other factors included in the model were parity $(1,2,3,4$ and higher), season of AI (winter, spring, summer, autumn), day in lactation of first AI, farm, and other non-CM diseases (retained placenta, metritis, ketosis, displaced abomasum). Data from 90,271 AI in 39,361 lactations in 20,328 cows collected from 2003/2004 to 2011 from 5 New York State dairy farms were analyzed in a generalized linear mixed model with a Poisson distribution. The largest reductions in probability of conception were associated with $\mathrm{CM}$ occurring in the week before AI or in the 2 wk following AI. Escherichia coli and Klebsiella spp. had the greatest adverse effects on probability of conception. The probability of conception for a cow with any combination of characteristics may be calculated based on the parameter estimates.

Received April 3, 2014.

Accepted July 18, 2014

${ }^{1}$ Corresponding author: jah12@cornell.edu
These findings may be helpful to farmers in assessing reproduction in their dairy cows for more effective cow management.

Key words: conception, bovine mastitis, pathogen, linear mixed model

\section{INTRODUCTION}

Successful reproduction of dairy cows is crucial to a dairy farm's livelihood. Both newborn calves and the maintenance of the cows' lactational cycles are important for a farm to thrive. When conception is delayed, or does not occur, it is a matter of great concern. Clinical mastitis (CM), a common problem in the dairy industry, can disrupt the fertility cycle (Santos et al., 2004; Hertl et al., 2010). Other factors interfering with conception include heat stress (Huang et al., 2008), high milk yield (Gustafsson and Emanuelson, 2002), and diseases other than mastitis (Fourichon et al., 2000). To minimize disruptions and irregularities in the fertility cycle, many farms use ovulation synchronization and planned breeding (AI) programs. The use of such interventions, however, is not a perfect solution. Cows still experience fertility problems due to the factors noted above.

The focus of the current study was the effect of CM due to different pathogens, occurring in different weekly time intervals before or after AI, on the probability of conception. We previously reported on the effects of CM caused by gram-negative and gram-positive bacteria and other organisms on probability of conception and found that all 3 types of CM reduced probability of conception, with gram-negative bacteria (comprising Escherichia coli, Klebsiella spp., Citrobacter spp., and Enterobacter spp.) having the greatest effect (Hertl et al., 2010). Since completion of that report, we have continued to collect data on CM from 5 of the 7 farms in that study and have now amassed sufficient data to study the effects of CM at the pathogen-specific level. Although several studies have examined the effects of different CM pathogens on various aspects of reproduction in dairy cows (Moore et al., 1991; Hockett et al., 2005; Wilson et al., 2008), to our knowledge none have 
combined this information with timing of $\mathrm{CM}$ cases in specific intervals before or after AI.

The objective of the current study was to estimate the effects of different types of CM, due to different pathogens and occurring in different weekly intervals before or after AI, as well as other factors, on the probability of conception in New York State Holstein dairy cows.

\section{MATERIALS AND METHODS}

\section{Herd Descriptions}

Data on 90,271 AI in 39,361 lactations in 20,328 cows in 5 large, well-managed, high-producing Holstein herds in New York State were collected beginning in January 2003 (1 herd), February 2004 (2 herds), or June 2004 (2 herds) and continuing until July 2011, and analyzed. Three herds were in central New York State, 1 was in northern New York State, and 1 was in western New York State. The 305-d rolling herd average milk production ranged from 11,260 to $13,123 \mathrm{~kg} /$ cow per year, and monthly mean SCC ranged from 137,000 to 262,000 cells $/ \mathrm{mL}$. The farms recorded information on milk production and milk electrical conductivity, parity, reproduction, diseases, calving, drying-off, and herd exit using the DairyComp305 herd management software (Valley Agricultural Software, Tulare, CA). Cows were housed in freestalls in covered barns and managed in groups according to lactation month, production, and reproduction status. They were fed a balanced TMR and milked 3 times per day.

All cows in the study herds participated in ovulation synchronization and planned breeding programs. The study herds were selected for this reason, as such programs remove many potential biases that can arise when herd managers make decisions regarding estrus detection and breeding (Hertl et al., 2010). In the study herds, pregnancy checking and diagnosis was conducted at approximately $35 \mathrm{~d}$ post-AI, by either palpation or ultrasound, depending on the farm. Open cows were given GnRH, prostaglandin, or both, and resynchronized. Pregnancy rechecks were conducted between 50 and $95 \mathrm{~d}$, depending on the farm. One farm did not perform rechecks, but instead watched cows for estrus and rebred any that may have previously been called pregnant.

\section{Case Definition}

All lactating cows that were inseminated for the first time between 40 and 90 DIM in the current lactation were eligible for inclusion in the study. Although a small proportion $(5.5 \%)$ of cows in the study herds were first inseminated outside of this interval, they were not considered to have been inseminated normally. The voluntary waiting period in the study farms was $60 \mathrm{~d}$ (i.e., it was farm practice to plan the first insemination at approximately 60 DIM). Because these farms practiced synchronized breeding programs that are often on a weekly injection schedule, some cows may have started synchronization somewhat early. In some cows that were expressing strong heat symptoms, insemination would occur outside the synchronization schedule.

Milkers detected most CM cases, which presented as a warm, swollen udder or changes in milk consistency. Herdspersons also found cases in cows with elevated milk electrical conductivity ( $>115 \%$ of the average of the previous $10 \mathrm{~d}$ ) and sudden concurrent milk loss $(<70 \%$ of the average of the previous $10 \mathrm{~d}$; Hertl et al., 2014). Such cows were then examined further for signs of CM. Sick cows were treated similarly on all 5 farms throughout the study, according to well-defined protocols (Cha et al., 2014). Microbiological diagnosis of milk samples from quarters with CM signs was performed at 3 of the Quality Milk Production Services laboratories (Ithaca, Canton, and Geneseo, NY); detailed information may be found in Gröhn et al. (2004).

If a second episode of CM occurred in the same quarter within $5 \mathrm{~d}$ after the first episode (with the same or a different pathogen isolated) or occurred within $14 \mathrm{~d}$ with the same pathogen isolated from both episodes, it was considered to be the same case of CM. Any episode occurring more than $14 \mathrm{~d}$ after the previous one, regardless of the pathogen isolated, was considered to be a new CM case (Barkema et al., 1998).

The pathogens included in the analysis were Streptococcus spp. [including Strep. dysgalactiae, Strep. uberis, other gram-positive catalase-negative cocci (such as Strep. aerococcus, Strep. enterococcus, Strep. lactococcus), and other Streptococcus spp.]; Staphylococcus aureus; staphylococci other than Staph. aureus (referred to as CNS throughout); Escherichia coli; Klebsiella spp.; cases with CM signs but no bacterial growth (above the level that can be detected using our microbiological procedures) observed in the culture sample, and cases with contamination $(\geq 3$ pathogens in the sample); and other pathogens (including Citrobacter, yeasts, Trueperella pyogenes, gram-negative bacilli (i.e., gram-negative organisms other than E. coli, Klebsiella spp., Enterobacter, and Citrobacter), Corynebacterium bovis, Corynebacterium spp., Pasteurella, Enterococcus, Pseudomonas, Mycoplasma, Prototheca, and others).

For the purposes of this study, where conception associated with the first $4 \mathrm{AI}$ was of interest, conception status was based on either a repeated insemination (no conception as a result of the previous insemination) or the result of rectal pregnancy checks by the herd veterinarian. 


\section{Other Diseases}

Besides CM, several other diseases were included as potential confounders. These were milk fever, retained placenta, metritis, ketosis, and displaced abomasum (DA). They were defined (Gröhn et al., 2004) as follows: (1) milk fever: a cow could not rise or had cool extremities and sluggish rumen motility near the time of calving, but was successfully treated with calcium; (2) retained placenta: retention of fetal membranes for $\geq 24$ h after calving; (3) metritis: the cow had a fever and a purulent or fetid vaginal discharge, or an enlarged uterus detected by veterinary palpation; (4) ketosis: presence of ketones in milk or urine, and response to treatment; and (5) DA: an abomasum enlarged with gas, fluid, or both, and that was mechanically trapped in either the right or left side of the abdominal cavity. Written disease definitions and diagnostic criteria were provided to participating dairy producers and veterinarians to ensure uniformity.

\section{Statistical Analysis}

The outcome variable was whether or not a cow conceived following a particular AI. The independent variables included are described below. A set of 12 variables was created, indicating when CM occurred (if it occurred) with respect to time of an AI and the causative pathogen. The variables covered the period from 6 wk before an AI until 6 wk after an AI, in weekly intervals, for CM occurring 36 to $42 \mathrm{~d}, 29$ to $35 \mathrm{~d}, 22$ to $28 \mathrm{~d}, 15$ to $21 \mathrm{~d}, 8$ to $14 \mathrm{~d}, 1$ to $7 \mathrm{~d}$ before, and 0 to 7 d, 8 to 14 d, 15 to 21 d, 22 to 28 d, 29 to 35 d, and 36 to $42 \mathrm{~d}$ after an AI. Artificial inseminations having 2 or more $\mathrm{CM}$ episodes in this 12 -wk period around an AI were not included in the analysis (Hertl et al., 2010), as it would not be possible to determine which CM case was contributing to the probability of conception associated with a particular AI. When 2 pathogens occurred in one CM case (e.g., cow number 4 in Table 1), 1 pathogen was chosen as the leading cause according to their expected severity of effects in the cow (Hassan et al., 2009). Table 1 shows how the CM variables were coded for 4 example cows in the data set.

Other variables included in the analysis were parity (1, 2, 3, 4 and higher), season of AI [winter (January, February, March), spring (April, May, June), summer (July, August, September), autumn (October, November, December)], AI attempt (first, second, third, fourth), day of lactation of first AI, farm, and other diseases (milk fever, retained placenta, metritis, ketosis, DA).

Because the data set contained repeated measures (up to 4 AI per lactation), it was analyzed in SAS PROC GLIMMIX (version 9.2, 2009; SAS Institute
Inc., Cary, NC). A model with a Poisson distribution for the response was considered appropriate as these were count data (number of AI). We fit the following generalized linear mixed model:

$$
g(\mathbf{Y})=\mathbf{X} \boldsymbol{\beta}+\varepsilon,
$$

where $g$ is a link function (here, the natural log of the odds of a cow conceiving after an AI), $\mathbf{Y}$ is the vector of observations $(0=$ did not conceive, $1=$ conceived $)$, $\boldsymbol{\beta}$ is an unknown vector of fixed-effect parameters with known design matrix $\mathbf{X}$, and $\varepsilon$ is an unknown random error vector. A negative parameter estimate means that the cow with that characteristic is less likely to experience the event of interest; that is, to conceive. A positive parameter estimate means that the cow with that characteristic is more likely to experience the event of interest; that is, to conceive. Statistical significance was defined at $P<0.05$.

Goodness of fit of the model was assessed by looking at the fit statistics -2 (residual log pseudo-likelihood), generalized chi-square, and generalized chi-square/ degrees of freedom. For the latter, a ratio of 1.0 is an indication of good model fit.

We calculated the probability, $P$, of an event (conception) occurring, due to the modeled factors, with the following formula:

$$
\begin{gathered}
P=\left[\exp \left(\beta_{0}+\beta_{1} \mathrm{x}_{1}+\beta_{2} \mathrm{x}_{2}+\ldots+\beta_{\mathrm{k}} \mathrm{x}_{\mathrm{k}}\right)\right] / \\
{\left[1+\exp \left(\beta_{0}+\beta_{1} \mathrm{x}_{1}+\beta_{2} \mathrm{x}_{2}+\ldots+\beta_{\mathrm{k}} \mathrm{x}_{\mathrm{k}}\right)\right],}
\end{gathered}
$$

where $P$ is the probability of conception associated with a particular $\mathrm{AI}, \beta_{0}$ is the regression parameter for the intercept, and $\beta_{1}, \beta_{2}, \ldots, \beta_{\mathrm{k}}$ are the regression parameters for the effects $\mathrm{x}_{1}, \mathrm{x}_{2}, \ldots, \mathrm{x}_{\mathrm{k}}$, respectively, in the model (Hertl et al., 2010).

Specification of a residual effect in the RANDOM statement of PROC GLIMMIX (SAS Institute, 2009) accounted for potential correlation of repeated AI within a lactation. The subject effect was a particular lactation of a specific cow in a specific herd. That is, events (AI) were correlated within each unique cow-lactation but were assumed independent among subjects (Hertl et al., 2010).

Least squares means; that is, means after controlling for other covariates in the model, were obtained for the levels of the fixed effects. Pairwise differences between levels or categories of each factor were assessed.

\section{RESULTS}

\section{Descriptive Findings}

A total of 97,869 first, second, third, and fourth AI events were recorded in the 5 herds during the study 
MASTITIS AND FERTILITY

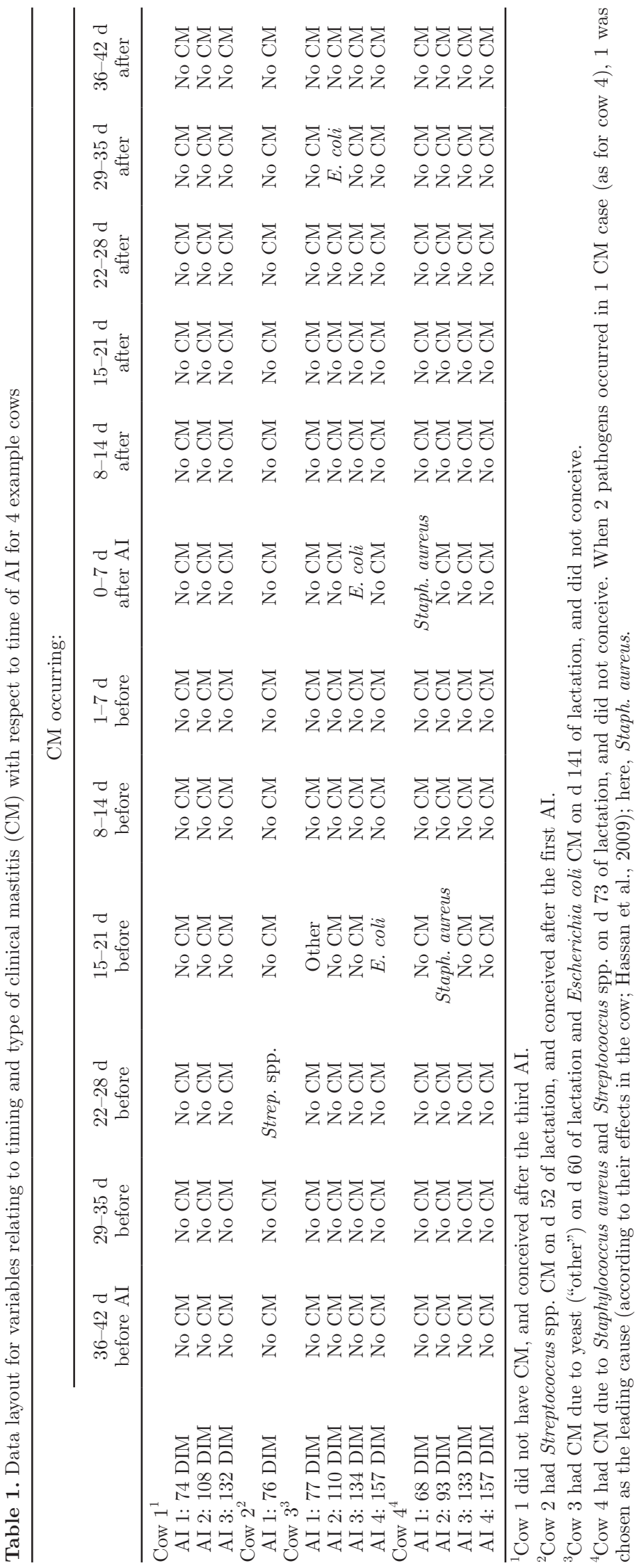


Table 2. Clinical mastitis (CM)-causing organisms (numbers ${ }^{1}$ ) in 39,361 lactations in 5 New York State Holstein herds, 2003-2011

\begin{tabular}{|c|c|c|c|c|c|}
\hline Organism & $\begin{array}{c}\text { All } \\
\text { lactations }\end{array}$ & Lactation 1 & Lactation 2 & Lactation 3 & Lactation $4+$ \\
\hline Streptococcus spp. ${ }^{2}$ & 4,445 & 1,001 & 1,496 & 1,020 & 928 \\
\hline Staphylococcus aureus & 1,194 & 341 & 412 & 252 & 189 \\
\hline CNS & 1,238 & 338 & 398 & 259 & 243 \\
\hline Escherichia coli & 4,200 & 933 & 1,404 & 998 & 865 \\
\hline Klebsiella spp. & 1,612 & 243 & 578 & 433 & 358 \\
\hline \multicolumn{6}{|l|}{ Cases with CM signs } \\
\hline No growth & 4,443 & 1,003 & 1,445 & 1,085 & 910 \\
\hline Contamination & 241 & 57 & 73 & 59 & 52 \\
\hline \multicolumn{6}{|l|}{ Other pathogens } \\
\hline Citrobacter & 7 & 1 & - & 1 & 5 \\
\hline Yeasts & 259 & 79 & 81 & 53 & 46 \\
\hline Trueperella pyogenes & 321 & 96 & 96 & 73 & 56 \\
\hline Gram-negative bacilli $^{3}$ & 4 & - & 1 & - & 3 \\
\hline Corynebacterium bovis & 61 & 22 & 15 & 14 & 10 \\
\hline Corynebacterium spp. & 1 & - & - & - & 1 \\
\hline Pasteurella spp. & 120 & 69 & 18 & 17 & 16 \\
\hline Enterococcus spp. & 1 & - & - & 1 & - \\
\hline Pseudomonas spp. & 29 & 8 & 9 & 4 & 8 \\
\hline Mycoplasma spp. & 124 & 62 & 34 & 18 & 10 \\
\hline Prototheca & 3 & - & 1 & 1 & 1 \\
\hline Others & 2,214 & 497 & 706 & 532 & 479 \\
\hline Unknown $^{4}$ & 1,178 & 339 & 371 & 274 & 194 \\
\hline
\end{tabular}

${ }^{1}$ Total number of CM cases (comprising first, second, third, and fourth occurrences in a lactation) in which the organism was identified. A cow could have more than one organism in an episode.

${ }^{2}$ Includes Strep. dysgalactiae, Strep. uberis, Streptococcus spp.

${ }^{3}$ Gram-negative organisms other than E. coli, Klebsiella spp., Enterobacter, and Citrobacter.

${ }^{4}$ These cases were not included in the analysis.

period. Of these, 5,515 first AI that occurred before 40 DIM or after 90 DIM were excluded. A further 2,083 AI having 2 or more $\mathrm{CM}$ episodes occurring within $6 \mathrm{wk}$ before to $6 \mathrm{wk}$ after the AI were also excluded. Thus, the final data set analyzed consisted of 90,271 AI, in 39,361 lactations in 20,328 cows in 5 herds.

Forty percent of cows were in their first lactation, $30 \%$ were in their second lactation, $17 \%$ were in their third lactation, and $13 \%$ were in their fourth or higher lactation. Inseminations took place throughout the calendar year, with approximately equal proportions occurring in each season (spring, summer, autumn, winter). Although it was farm practice to wait until 60 DIM to inseminate for the first time, $16 \%$ of study cows were first inseminated between 41 and 59 DIM (most in the latter part of this interval).

In the data set, $30.8 \%$ lactations had at least one CM case. Streptococcus spp. and E. coli were the most commonly isolated pathogens. Cases with CM signs but no bacterial growth also frequently occurred (Table 2). Regarding non-CM diseases, $1 \%$ of lactations experienced milk fever, $10 \%$ had retained placenta, $4 \%$ had metritis, $9 \%$ had ketosis, and 3\% had DA.

Regarding goodness of fit of the estimated model, the $-2 *$ residual log pseudo-likelihood was 336,408 ; generalized chi-square was 63,389 ; and the generalized chi-square/degrees of freedom was 0.7 .

\section{Effects of Variables (Other than CM) on Probability of Conception}

Tables 3 and 4 present results from a model including parity, insemination attempt, season of AI, day in lactation of first $\mathrm{AI}$, farm, non-CM diseases, and pathogen-specific CM occurring in different intervals with respect to time of AI. For ease of presentation, estimates for the non-CM variables are shown in Table 3 and estimates for the CM variables are shown in Table 4. All of the variables in both tables, however, appeared in the same model. Table 3 shows parameter estimates, standard errors, and 95\% CI for variables other than CM. As a cow aged, her probability of conception at a given AI decreased. Parity 2 cows had a $14 \%$ lower $[1-\exp (-0.15)]$ probability of conception $(P<0.0001)$ than did parity 1 cows. Parity 3 cows had a $15 \%$ lower $(P<0.0001)$ and parity $4+$ cows a $20 \%$ lower $(P<$ $0.0001)$ probability of conception than did parity 1 cows.

Of the 90,271 AI, $43 \%$ were the first in the studied lactation, $27 \%$ were the second, $18 \%$ were the third, and 
Table 3. Probability of conception: Parameter estimates, standard errors (SE), and 95\% CI for the non-CM factors in the generalized mixed model used to estimate the effects of clinical mastitis (CM) due to different pathogens, and other factors, in 39,361 lactations in 20,328 cows in 5 New York State herds ${ }^{1,2}$

\begin{tabular}{llccc}
\hline Parameter & Level & Estimate & SE & $95 \%$ CI \\
\hline Intercept & & $-0.97^{* * *}$ & 0.05 & $-1.06,-0.88$ \\
Parity & 1 & Ref. $^{3}$ & - & - \\
& 2 & $-0.15^{* * *}$ & 0.01 & $-0.17,-0.12$ \\
& 3 & $-0.17^{* * *}$ & 0.02 & $-0.20,-0.14$ \\
Insemination attempt (AI) & 4 & $-0.22^{* * *}$ & 0.02 & $-0.26,-0.19$ \\
& First & Ref. & - & - \\
& Second & $-0.13^{* * *}$ & 0.01 & $-0.15,-0.10$ \\
& Third & $-0.16^{* * *}$ & 0.01 & $-0.19,-0.13$ \\
Day in lactation of first AI & Fourth & $-0.21^{* * *}$ & 0.02 & $-0.24,-0.17$ \\
Season of AI & - & $0.0025^{* * *}$ & 0.0006 & $0.001,0.003$ \\
& Winter & Ref. & - & - \\
& Spring & -0.01 & 0.01 & $-0.03,0.02$ \\
Farm & Summer & $-0.20^{* * *}$ & 0.02 & $-0.22,-0.17$ \\
& Autumn & $-0.04^{*}$ & 0.01 & $-0.06,-0.01$ \\
& A & Ref. & - & - \\
& B & $-0.06^{* *}$ & 0.02 & $-0.10,-0.03$ \\
Retained placenta & C & $-0.20^{* * *}$ & 0.01 & $-0.23,-0.18$ \\
Metritis & D & $-0.15^{* * *}$ & 0.02 & $-0.18,-0.12$ \\
Ketosis & E & $-0.21^{* * *}$ & 0.02 & $-0.25,-0.18$ \\
& Absent & Ref. & - & - \\
Displaced abomasum & Present & $-0.22^{* * *}$ & 0.02 & $-0.26,-0.19$ \\
& Absent & Ref. & - & $-0.23,-0.09$ \\
\hline
\end{tabular}

${ }^{1}$ The estimates in Tables 3 and 4 derive from the same model.

${ }^{2}$ Most values have been rounded to 2 decimal places, so results presented in the text may differ slightly due to rounding.

${ }^{3}$ Reference level of the factor (estimate $=0.00$ ).

${ }^{*} P<0.05 ; * * P<0.01 ; * * P<0.001$.

$12 \%$ were the fourth. Conception was marginally less likely with each successive AI (assuming that the first AI took place on d 60 of lactation): $31 \%\{[\exp (-0.97$ $+60 \times 0.0025)] /[1+\exp (-0.97+60 \times 0.0025)]\}$ for the first, $28 \%\{[\exp (-0.97+60 \times 0.0025-0.13)] /[1$ $+\exp (-0.97+60 \times 0.0025-0.13)]\}$ for the second, $27 \%$ for the third, and $26 \%$ for the fourth. A cow was more likely to conceive if the first AI occurred later rather than earlier (within the interval 40-90 DIM), in lactation.

The study farms varied in the success of their breeding programs, with the worst farm experiencing $19 \%$ fewer conceptions than the best farm. Conception was least likely to occur when AI took place in the summer. Retained placenta, metritis, ketosis, and DA were all associated with a decrease in probability of conception.

\section{Effects of Pathogen-Specific CM on Probability of Conception}

Clinical mastitis occurring before an AI had little effect on probability of conception until 1 to $7 \mathrm{~d}$ before insemination (Table 4). The greatest effect of Strepto- coccus spp. CM on probability of conception was when it occurred from 0 to $7 \mathrm{~d}\{55 \%[1-\exp (-0.79)]$ less; $P<0.0001\}$ after AI. Staphylococcus aureus CM was associated with a lower probability of conception only when occurring from 0 to $7 \mathrm{~d}$. When CM due to CNS occurred 15 to $21 \mathrm{~d}$ after AI, it reduced the probability of conception, but when it occurred 29 to $35 \mathrm{~d}$ after AI, it increased the probability of conception.

Escherichia coli and Klebsiella spp. CM had their largest effects on probability of conception when occurring 0 to $7 \mathrm{~d}$ after AI. Clinical mastitis cases due to other pathogens and cases with signs but no growth also had their largest effects when occurring 0 to $7 \mathrm{~d}$ after AI.

As an example, Figure 1 shows the probability of conception associated with the first AI (assuming that it took place on d 60 of lactation), for a cow of parity 2 bred in autumn, with CM occurring in different intervals before or after AI. The horizontal line in each panel depicts the probability of conception for such a cow with no $\mathrm{CM}$ \{probability $=[\exp (-0.97+60 \times$ $0.0025-0.15-0.04)] /[1+\exp (-0.97+60 \times 0.0025$ $-0.15-0.04)]=0.27$; Table 3$\}$. The probabilities for 
Table 4. Probability of conception: Parameter estimates, standard errors (SE), and 95\% CI for the clinical mastitis (CM) variables in the generalized mixed model used to estimate the effects of CM due to different pathogens, and other factors, in 39,361 lactations in 20,328 cows in 5 New York State herds ${ }^{1,2}$

\begin{tabular}{|c|c|c|c|c|}
\hline Parameter & Level & Estimate & $\mathrm{SE}$ & $95 \% \mathrm{CI}$ \\
\hline Intercept & & $-0.97^{* * *}$ & 0.05 & $-1.06,-0.88$ \\
\hline \multirow[t]{8}{*}{ CM occurring $36-42 \mathrm{~d}$ before AI } & Streptococcus spp. & 0.13 & 0.12 & $-0.10,0.36$ \\
\hline & Staphylococcus aureus & -0.17 & 0.30 & $-0.75,0.42$ \\
\hline & CNS & 0.28 & 0.28 & $-0.27,0.83$ \\
\hline & Escherichia coli & 0.01 & 0.11 & $-0.20,0.22$ \\
\hline & Klebsiella spp. & -0.53 & 0.30 & $-1.11,0.05$ \\
\hline & Other pathogens & $0.42 *$ & 0.17 & $0.08,0.77$ \\
\hline & CM signs but no growth & -0.00 & 0.12 & $-0.23,0.23$ \\
\hline & None & Ref. $^{3}$ & - & \\
\hline \multirow[t]{8}{*}{ CM occurring 29-35 d before AI } & Streptococcus spp. & -0.14 & 0.14 & $-0.41,0.13$ \\
\hline & Staph. aureus & 0.25 & 0.25 & $-0.25,0.74$ \\
\hline & CNS & 0.54 & 0.30 & $-0.04,1.13$ \\
\hline & E. coli & 0.07 & 0.10 & $-0.13,0.26$ \\
\hline & Klebsiella spp. & -0.01 & 0.24 & $-0.48,0.47$ \\
\hline & Other pathogens & 0.21 & 0.19 & $-0.17,0.58$ \\
\hline & CM signs but no growth & -0.06 & 0.12 & $-0.30,0.17$ \\
\hline & None & Ref. & - & - \\
\hline \multirow{8}{*}{ CM occurring $22-28 \mathrm{~d}$ before AI } & Streptococcus spp. & -0.06 & 0.14 & $-0.33,0.21$ \\
\hline & Staph. aureus & 0.07 & 0.25 & $-0.43,0.57$ \\
\hline & CNS & 0.18 & 0.28 & $-0.37,0.72$ \\
\hline & E. coli & 0.13 & 0.10 & $-0.05,0.32$ \\
\hline & Klebsiella spp. & 0.05 & 0.21 & $-0.36,0.46$ \\
\hline & Other pathogens & 0.03 & 0.22 & $-0.42,0.47$ \\
\hline & CM signs but no growth & 0.08 & 0.10 & $-0.12,0.27$ \\
\hline & None & Ref. & - & - \\
\hline \multirow[t]{8}{*}{ CM occurring $15-21 \mathrm{~d}$ before AI } & Streptococcus spp. & -0.18 & 0.13 & $-0.44,0.08$ \\
\hline & Staph. aureus & 0.15 & 0.30 & $-0.43,0.73$ \\
\hline & CNS & -0.23 & 0.34 & $-0.91,0.44$ \\
\hline & E. coli & 0.07 & 0.09 & $-0.11,0.25$ \\
\hline & Klebsiella spp. & -0.31 & 0.28 & $-0.86,0.24$ \\
\hline & Other pathogens & -0.20 & 0.23 & $-0.66,0.25$ \\
\hline & CM signs but no growth & $0.27^{* *}$ & 0.10 & $0.07,0.47$ \\
\hline & None & Ref. & - & - \\
\hline \multirow{8}{*}{ CM occurring 8-14 d before AI } & Streptococcus spp. & $-0.28^{*}$ & 0.13 & $-0.54,-0.02$ \\
\hline & Staph. aureus & -0.70 & 0.42 & $-1.52,0.13$ \\
\hline & CNS & 0.05 & 0.30 & $-0.54,0.63$ \\
\hline & E. coli & -0.08 & 0.11 & $-0.29,0.13$ \\
\hline & Klebsiella spp. & 0.04 & 0.24 & $-0.44,0.52$ \\
\hline & Other pathogens & $0.37^{*}$ & 0.19 & $0.00,0.74$ \\
\hline & CM signs but no growth & -0.09 & 0.13 & $-0.34,0.16$ \\
\hline & None & Ref. & - & - \\
\hline \multirow{8}{*}{ CM occurring $1-7 \mathrm{~d}$ before AI } & Streptococcus spp. & $-0.47^{*}$ & 0.18 & $-0.83,-0.11$ \\
\hline & Staph. aureus & -0.46 & 0.34 & $-1.14,0.21$ \\
\hline & CNS & -0.13 & 0.34 & $-0.80,0.54$ \\
\hline & E. coli & $-0.69^{* * *}$ & 0.19 & $-1.06,-0.32$ \\
\hline & Klebsiella spp. & $-1.32^{* *}$ & 0.48 & $-2.27,-0.37$ \\
\hline & Other pathogens & $-1.31^{*}$ & 0.59 & $-2.48,-0.15$ \\
\hline & CM signs but no growth & -0.28 & 0.15 & $-0.58,0.02$ \\
\hline & None & Ref. & - & - \\
\hline \multirow[t]{8}{*}{$\mathrm{CM}$ occurring $0-7 \mathrm{~d}$ after $\mathrm{AI}$} & Streptococcus spp. & $-0.79^{* * *}$ & 0.18 & $-1.15,-0.43$ \\
\hline & Staph. aureus & $-1.04^{*}$ & 0.42 & $-1.86,-0.22$ \\
\hline & CNS & -0.54 & 0.38 & $-1.27,0.20$ \\
\hline & E. coli & $-1.69 * * *$ & 0.22 & $-2.12,-1.27$ \\
\hline & Klebsiella spp. & $-1.33^{* * *}$ & 0.38 & $-2.06,-0.59$ \\
\hline & Other pathogens & $-1.05^{* *}$ & 0.34 & $-1.72,-0.38$ \\
\hline & CM signs but no growth & $-0.53^{* * *}$ & 0.15 & $-0.82,-0.24$ \\
\hline & None & Ref. & - & - \\
\hline \multirow[t]{8}{*}{ CM occurring 8-14 d after AI } & Streptococcus spp. & -0.23 & 0.13 & $-0.49,0.02$ \\
\hline & Staph. aureus & -0.10 & 0.25 & $-0.60,0.40$ \\
\hline & CNS & -0.12 & 0.30 & $-0.71,0.46$ \\
\hline & E. coli & $-0.77^{* * *}$ & 0.16 & $-1.08,-0.47$ \\
\hline & Klebsiella spp. & $-0.96^{* *}$ & 0.32 & $-1.58,-0.34$ \\
\hline & Other pathogens & $-0.97^{* *}$ & 0.32 & $-1.59,-0.35$ \\
\hline & CM signs but no growth & $-0.27^{*}$ & 0.13 & $-0.51,-0.02$ \\
\hline & None & Ref. & - & - \\
\hline
\end{tabular}


Table 4 (Continued). Probability of conception: Parameter estimates, standard errors (SE), and 95\% CI for the clinical mastitis (CM) variables in the generalized mixed model used to estimate the effects of CM due to different pathogens, and other factors, in 39,361 lactations in 20,328 cows in 5 New York State herds ${ }^{1,2}$

\begin{tabular}{llccc}
\hline Parameter & Level & Estimate & SE & $95 \%$ CI \\
\hline CM occurring 15-21 d after AI & Streptococcus spp. & -0.02 & 0.12 & $-0.25,0.22$ \\
& Staph. aureus & -0.23 & 0.27 & $-0.75,0.29$ \\
& CNS & $-1.10^{*}$ & 0.48 & $-2.05,-0.15$ \\
& E. coli & $-0.78^{* * *}$ & 0.15 & $-1.07,-0.49$ \\
& Klebsiella spp. & $-0.75^{* *}$ & 0.28 & $-1.30,-0.20$ \\
& Other pathogens & -0.33 & 0.25 & $-0.83,0.17$ \\
& CM signs but no growth & -0.20 & 0.13 & $-0.45,0.04$ \\
CM occurring 22-28 d after AI & None & Ref. & - & - \\
& Streptococcus spp. & $-0.42^{* *}$ & 0.15 & $-0.72,-0.13$ \\
& Staph. aureus & 0.15 & 0.22 & $-0.28,0.57$ \\
& CNS & -0.18 & 0.30 & $-0.76,0.40$ \\
& E. coli & $-0.49^{* * *}$ & 0.13 & $-0.74,-0.24$ \\
& Klebsiella spp. & $-0.57^{*}$ & 0.28 & $-1.12,-0.02$ \\
& Other pathogens & -0.27 & 0.25 & $-0.77,0.22$ \\
CM occurring 29-35 d after AI & CM signs but no growth & -0.18 & 0.12 & $-0.41,0.05$ \\
& None & Ref. & - & - \\
& Streptococcus spp. & $-0.29^{*}$ & 0.13 & $-0.55,-0.03$ \\
& Staph. aureus & -0.40 & 0.27 & $-0.92,0.12$ \\
& CNS & $0.44^{*}$ & 0.22 & $0.02,0.87$ \\
& E. coli & -0.16 & 0.11 & $-0.38,0.07$ \\
& Klebsiella spp. & -0.29 & 0.23 & $-0.74,0.17$ \\
& Other pathogens & -0.32 & 0.25 & $-0.82,0.17$ \\
& CM signs but no growth & -0.09 & 0.12 & $-0.32,0.14$ \\
& None & Ref. & - & -12 \\
& Streptococcus spp. & -0.16 & 0.13 & $-0.42,0.10$ \\
& Staph. aureus & 0.05 & 0.22 & $-0.38,0.48$ \\
& CNS & -0.17 & 0.27 & $-0.69,0.35$ \\
& E. coli & 0.04 & 0.11 & $-0.17,0.25$ \\
& Klebsiella spp. & -0.16 & 0.21 & $-0.58,0.25$ \\
& Other pathogens & -0.04 & 0.22 & $-0.48,0.40$ \\
& CM signs but no growth & 0.00 & 0.11 & $-0.22,0.22$ \\
& None & Ref. & - & - \\
\hline
\end{tabular}

${ }^{1}$ The estimates in Tables 3 and 4 derive from the same model.

${ }^{2}$ Values have been rounded to 2 decimal places, so results presented in the text may differ slightly due to rounding.

${ }^{3}$ Reference level of the factor (estimate $\left.=0.00\right)$.

${ }^{*} P<0.05 ;{ }^{* *} P<0.01 ;{ }^{* * *} P<0.001$.

each type of CM (E. coli and Klebsiella spp. in Figure 1A; Streptococcus spp. and Staph. aureus in Figure 1B; CNS, "other pathogens," and CM with signs but no growth in Figure 1C) were calculated from the estimates in Tables 3 and 4. Several pathogens had a large adverse effect when occurring immediately before AI (e.g., probability of conception for Klebsiella spp. CM occurring 1 to $7 \mathrm{~d}$ before AI decreased to only 0.09 $\{[\exp (-0.97+60 \times 0.0025-0.15-0.04-1.32)] /[1$ $+\exp (-0.97+60 \times 0.0025-0.15-0.04-1.32)]\}$ for the example cow (Figure 1A). Clinical mastitis occurring shortly after AI was most likely to reduce the probability of conception. For example, if the cow contracted E. coli CM within a week after AI, her probability of conception decreased to only 0.06 (Figure 1A). In a few instances, CM was associated with an increased probability of conception (Figure 1C).

Probability of conception also differed among some pathogens (Table 5), as assessed by differences in their least squares means. In general, E. coli and Klebsiella spp. had larger negative effects on the probability of conception than did the other study pathogens.

\section{DISCUSSION}

These results indicate a strong relationship between $\mathrm{CM}$ and fertility. Clinical mastitis due to virtually all pathogens was associated with a lower fertility. Not unexpectedly, some significant differences between cases of mastitis due to different pathogens were observed. In the current study, E. coli and Klebsiella spp., both of which are gram-negative organisms, had greater detrimental effects on probability of conception than did the other study pathogens. Previous studies, including Herath et al. (2009) and Hertl et al. (2010), have documented the adverse effects of gram-negative organisms on reproduction. In the current study, both E. coli and Klebsiella spp. CM reduced probability of conception 

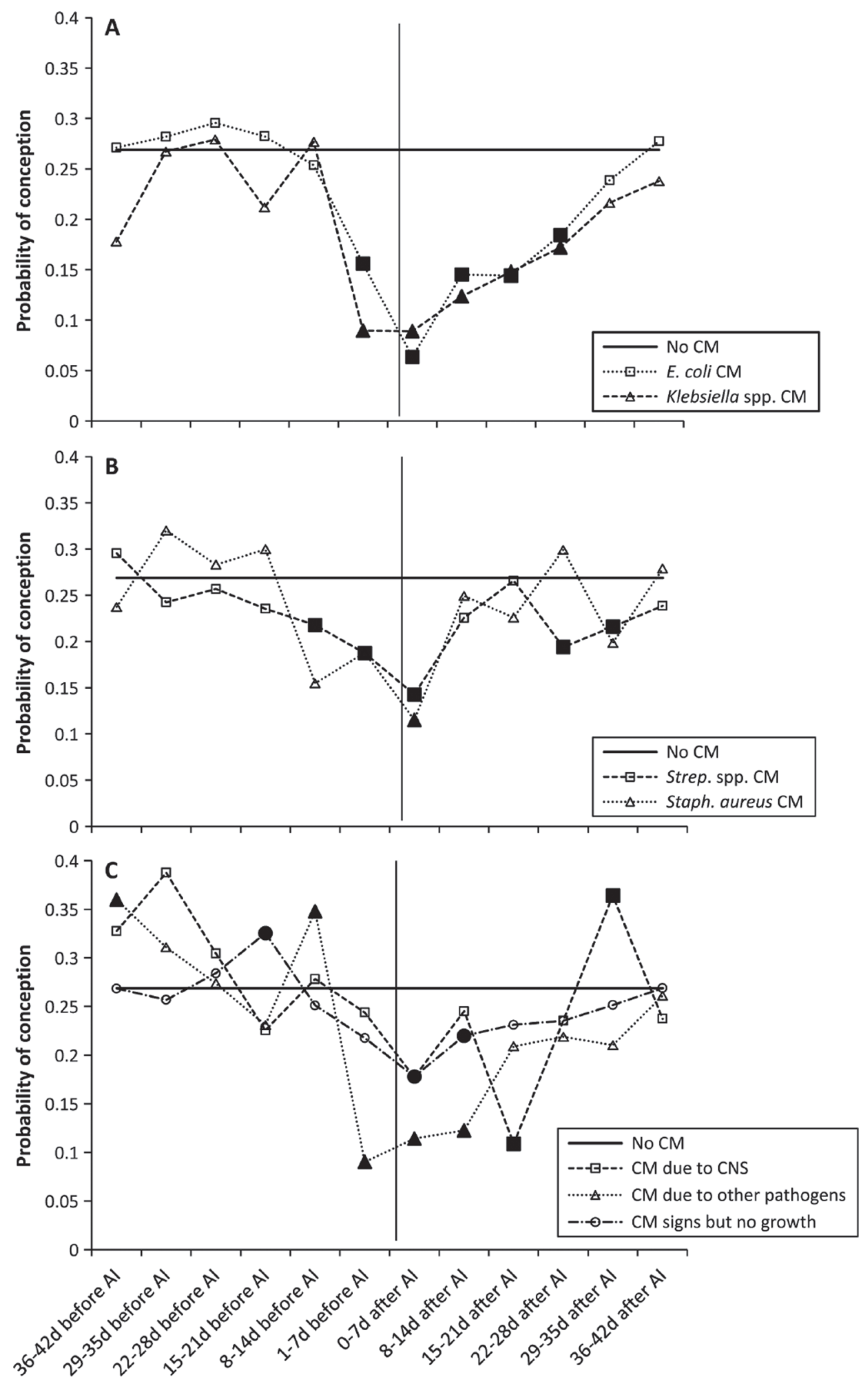

CM relative to first AI (d)

Figure 1. Probability of conception on first AI, for a parity 2 cow bred in autumn, without clinical mastitis $(\mathrm{CM})$ or with CM caused by different organisms or organism groups. Larger, filled symbols indicate probabilities that were significantly different $(P<0.05)$ compared with "No CM" in the interval. The vertical dotted line indicates CM occurring before vs. after AI. 
Table 5. Pathogens that differed significantly (at $\alpha=0.05)$ from each other, and their parameter estimates (see Table 4$)$ in terms of their effect on probability of conception, as estimated by least squares means for the model, in each time interval of when clinical mastitis (CM) occurred in relation to an $\mathrm{AI}^{1}$

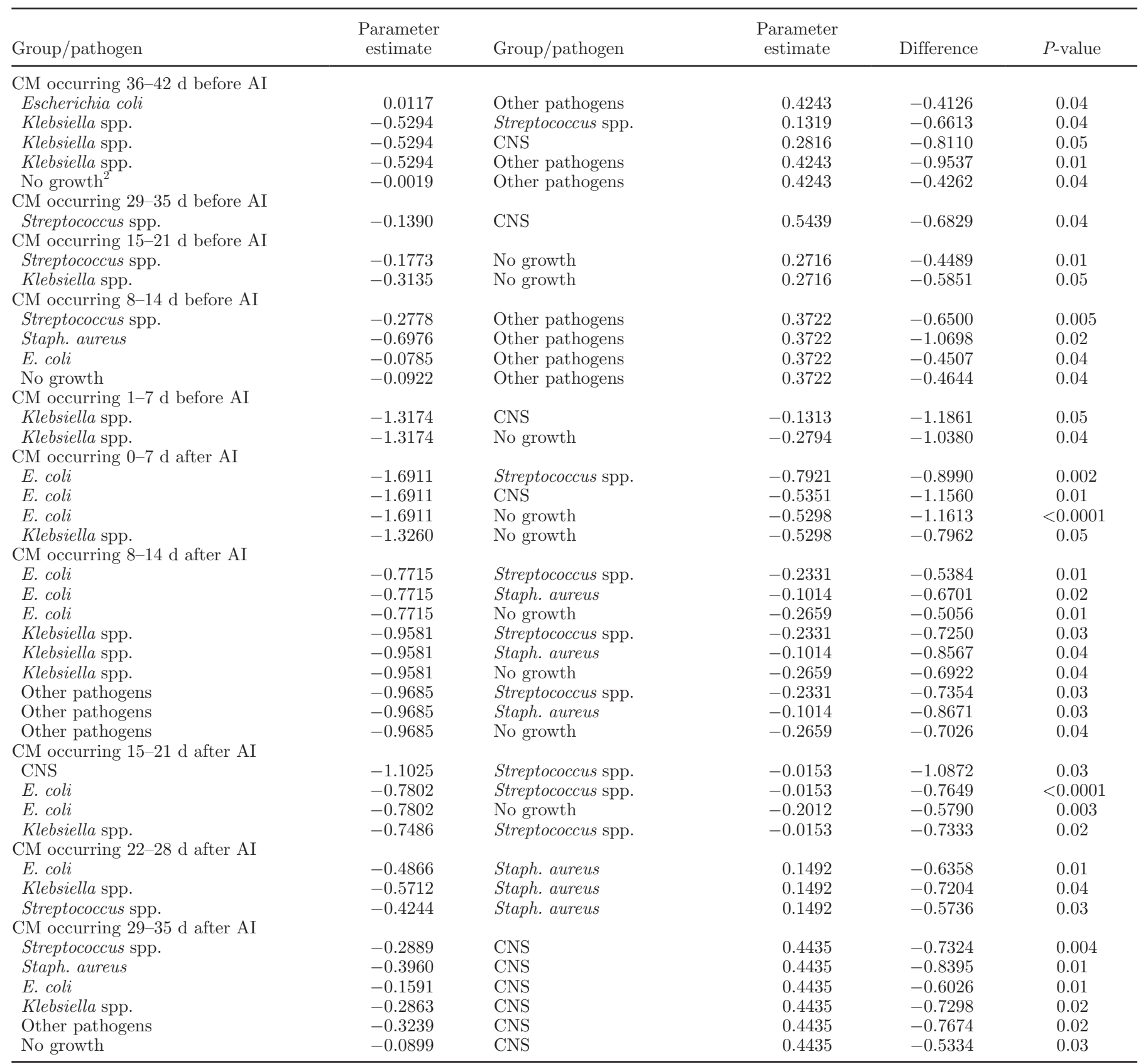

${ }^{1}$ No significant differences were found among pathogens in the intervals "CM occurring 22-28 d before AI" and "CM occurring 36-42 d after AI."

${ }^{2} \mathrm{CM}$ signs but no growth on culture.

when it occurred in the week before AI and at any time up to 4 wk after AI. Similarly, Wilson et al. (2008) found that cows with E. coli or Klebsiella $\mathrm{CM}$ needed more services per conception than did their herdmates without these types of CM.

In this study, Streptococcus spp. (Strep. dysgalactiae, Strep. uberis, and other Streptococcus spp.) CM reduced probability of conception both before and after AI (Table 4), with the greatest effect when it occurred 0 to $7 \mathrm{~d}$ after AI. This was in close agreement with a study by Wilson et al. (2008). Similarly, Hockett et al. (2005) found that cows experimentally infected with Strep. uberis were more likely to exhibit signs of impaired reproductive performance, including lack of 
estrous behavior, LH surge, and ovulation, among other signs.

Staphylococcus aureus CM only affected probability of conception when it occurred immediately after AI. In a California herd in which Staph. aureus was the most commonly occurring pathogen, cows with $\mathrm{CM}$ were slightly less likely than their nonmastitic herdmates to have an estrus interval outside the normal range (18-24 d), although the difference was not statistically significant (Moore et al., 1991). In contrast, in another California herd in the same study, where gram-negative organisms, particularly E. coli, were most prevalent, cows with CM were nearly twice as likely to have an estrus interval outside this range. Those authors speculate that subclinical Staph. aureus may be protective against more severe coliform infections. Other differences between the herds, including heat detection efficiency and management practices, may also play a role (Moore et al., 1991).

Clinical mastitis due to CNS had no effect on probability of conception except when it occurred 15 to $21 \mathrm{~d}$ (reduction of $67 \%$ ) or 29 to $35 \mathrm{~d}$ (increase of $55 \%$ ) after AI. Coagulase-negative staphylococci are often considered "minor" pathogens, as they generally have few detrimental effects (in contrast to a major pathogen such as E. coli; Reyher et al., 2012). Lam et al. (1997) reported that quarters infected with minor pathogens were less likely than uninfected quarters to become infected with major pathogens. Thus, it may not be too surprising that a cow infected with a minor pathogen such as CNS may not have any important consequences for reproduction. Three-quarters of IMI (both clinical and subclinical) reported in heifers in 9 herds in a multi-state study were due to CNS (Borm et al., 2006). These pathogens, however, appeared to have no effect on reproduction, as measured by services per conception or days open, because no differences were observed between heifers treated and not treated with intramammary antibiotics prepartum (Borm et al., 2006).

Clinical mastitis due to other pathogens increased the probability of conception in 3 intervals before AI, but decreased it in the week immediately preceding AI and in the 2 wk immediately after AI. Two possible factors explain the increased conception observed in our study. First, it may be an artifact of statistical testing: at an $\alpha$-level of 0.05 , one would expect $5 \%$ of results to be statistically significant, whether they truly are or not. Second, many different pathogens are included in the "other" category, and we do not know which specific pathogen(s) was involved. Also, some infections are mild initially and resolve spontaneously (e.g., those due to Enterobacter spp.; Schukken et al., 2012). In our recent study on the effects of pathogen-specific CM on milk yield (Hertl et al., 2014), we found that CNS, unlike the other pathogens studied, were not associated with milk loss. In that study, we speculated that "minor" pathogens (such as CNS) have a protective effect against "major" pathogens (such as E. coli), as Lam et al. (1997) reported. A similar effect on reproduction may be occurring (if the other pathogen is a minor one) or if these cows for one or more unknown reasons are more likely to conceive.

Cases of CM with signs but no bacterial growth were common findings in the study herds. These cases, however, did not generally have a large effect on the probability of conception. In a previous study, a higher rate of premature luteolysis and longer follicular phase occurred in Hungarian Holstein cows with mastitis caused by either gram-negative or no detected pathogens compared with cows with gram-positive or no mastitis. Release of endotoxin from gram-negative and "no detected pathogen" (many of which were actually probably gram-negative) cases is likely involved (Huszenicza et al., 2005).

Table 5 presents a comparison of some of the pathogens, where they differed in their effects on probability of conception within the same time interval. The largest difference was between Klebsiella spp. and CNS occurring 1 to $7 \mathrm{~d}$ before AI, followed by E. coli and CNS occurring 0 to $7 \mathrm{~d}$ after AI. Similarly, Wilson et al. (2008) found E. coli and Klebsiella to have adverse effects on reproductive performance but CNS to have no effect. The reason for these differences, as mentioned above, may be that if a cow is already infected with a minor pathogen, such as CNS, a subsequent infection with a major pathogen such as E. coli may be prevented (Lam et al., 1997). Thus, only the lesser effects of the minor pathogen will manifest themselves. Without the presence of the minor pathogen, the greater effects of the major pathogen would be evident instead.

The effects of CM likely differ whether it occurs before or after AI, although the end result is the same: a lower probability of a confirmed pregnancy. When $\mathrm{CM}$ occurs before AI, the reproductive system may be too impaired to initiate a pregnancy, due to estrus cycle disruptions (Hockett et al., 2005; Williams et al., 2008; Herath et al., 2009). Alternatively, even if the embryo does successfully implant in the uterus, it may be lost before pregnancy is confirmed (Moore et al., 2005). Recently, several reports have been published on the interaction between pathogens and fertility, specifically on the proposed mechanisms of action in the case of LPS sensing by toll-like receptors (Bromfield and Sheldon, 2011; Cronin et al., 2012). It was shown that LPS perturbs oocyte meiotic progression through the toll-like receptor-4 pathway. As shown in our data, the strongest effect of CM before $\mathrm{AI}$ on conception was due 
to gram-negative organisms, all of which have LPS in their cell walls. This relationship between LPS and meiotic progression is of increasing interest due not only to mastitis but also to presence of gram-negative organisms in the uterus immediately before AI (Bromfield and Sheldon, 2011).

When CM occurs after AI, the embryo may have already implanted in the uterus but be aborted before the pregnancy is confirmed (Risco et al., 1999; Hansen et al., 2004). In these cases, embryo loss may occur due in part to the actions of proinflammatory cytokines (Hansen et al., 2004) or the inflammatory pathway leading to prostaglandin production and subsequent luteotrophic effects of these prostaglandins (Herath et al., 2009). This early embryonic death is very common and frequently acknowledged in published papers (e.g., Bridges et al., 2013).

Although some studies have found milk yield to have an effect on reproduction [higher milk yield was associated with a higher risk of being a repeat breeder (Gustafsson and Emanuelson, 2002) and with decreased probability of conception (Hudson et al., 2012)], others have not found these associations (López-Gatius et al., 2002; Chebel et al., 2004). Contemporaneous milk yield was not modeled in the current study. Milk yield at the time of $\mathrm{AI}$ is an intervening variable in the relationship between CM and conception, so it would be difficult to determine how much of the $\mathrm{CM}$ effect on probability of conception is due to $\mathrm{CM}$ alone and how much is acting through milk yield. Milk production potential as measured through early-lactation milk production before both $\mathrm{CM}$ and $\mathrm{AI}$ was previously shown not to be related to conception risk (Hertl et al., 2010). Furthermore, the main interest of the current study was the effect of CM, not milk yield, on probability of conception.

The results of this study are generalizable to other herds with similar characteristics (i.e., large, wellmanaged, high-producing herds). From a biological perspective, the results can also probably be generalized to other herds that differ to some extent, as the pathogens are infecting individual cows within a herd. The findings, however, would not necessarily be as generalizable to farms using either no or a substantially different ovulation synchronization program. Conception is probably less likely to occur naturally (i.e., with no program in place) than when some type of planned breeding program is in place. Furthermore, farms performing pregnancy checks at different time intervals post-AI would exhibit varying conception probabilities. Pregnancy loss is substantial between 30 and $45 \mathrm{~d}$ postAI but much less common after $45 \mathrm{~d}$.

A valuable feature of this study is that the probability of conception for a cow with any combination of characteristics can be calculated, based on the estimates in
Tables 3 and 4 . Such calculations indicate the extent of the effect of different types of CM, and when they occur in relation to insemination, on probability of conception. They may be helpful, therefore, in determining the optimal allocation of resources (e.g., semen, labor, treatment costs) and management of reproduction. For example, it might be better to delay insemination in cows with certain types of CM. For cows that contract CM shortly after AI (e.g., the cow with E. coli in the above example), this is a moot point given that $\mathrm{AI}$ has occurred, but the farmer should keep in mind that such cows will very likely not conceive and will need to be reinseminated, and should account for this in management plans. In future, interventions that counteract the effect of pathogen-associated molecular patterns, such as LPS, may become available and would be of specific value to reduce the effect of IMI on subsequent reproductive outcomes.

\section{CONCLUSIONS}

This study estimated the effects of CM, due to different pathogens and occurring in different weekly intervals before or after $\mathrm{AI}$, and other factors on the probability of conception in Holstein cows in 5 New York State dairy farms. Cases of CM, whether occurring immediately before or up until 4 wk after AI, had a strong negative effect on the probability of conception. The greatest reductions in probability of conception were observed when CM occurred in the week before AI or at some time in the first 2 wk after AI. Escherichia coli and Klebsiella spp. were associated with the largest reductions in probability of conception. Clinical mastitis cases due to the other pathogens studied here were also associated with lower probabilities of conception, albeit to a lesser extent. The probability of conception for a cow with any combination of characteristics may be calculated from the estimates provided. Such information may be beneficial to farmers in their attempts to optimize reproduction and management of their dairy cows.

\section{ACKNOWLEDGMENTS}

The USDA (CSREES; Washington, DC) Award No. 2010-65119-20478 provided funding for this study. The authors thank owners and personnel from the 5 dairies, and the personnel of the Ithaca, Canton, and Geneseo regional laboratories of Quality Milk Production Services, for their valuable cooperation.

\section{REFERENCES}

Barkema, H. W., Y. H. Schukken, T. J. Lam, M. L. Beiboer, H. Wilmink, G. Benedictus, and A. Brand. 1998. Incidence of clinical mas- 
titis in dairy herds grouped in three categories by bulk milk somatic cell counts. J. Dairy Sci. 81:411-419.

Borm, A. A., L. K. Fox, K. E. Leslie, J. S. Hogan, S. M. Andrew, K. M. Moyes, S. P. Oliver, Y. H. Schukken, D. D. Hancock, C. T. Gaskins, W. E. Owens, and C. Norman. 2006. Effects of prepartum intramammary antibiotic therapy on udder health, milk production, and reproductive performance in dairy heifers. J. Dairy Sci. 89:2090-2098.

Bridges, G. A., M. L. Day, T. W. Geary, and L. H. Cruppe. 2013 Triennial Reproduction Symposium: Deficiencies in the uterine environment and failure to support embryonic development. J. Anim. Sci. 91:3002-3013.

Bromfield, J. J., and M. Sheldon. 2011. Lipopolysaccharide initiates inflammation in bovine granulosa cells via the TLR4 pathway and perturbs oocyte meiotic progression in vitro. Endocrinology 152:5029-5040.

Cha, E., A. R. Kristensen, J. A. Hertl, Y. H. Schukken, L. W. Tauer, F. L. Welcome, and Y. T. Gröhn. 2014. Optimal insemination and replacement decisions to minimize the cost of pathogen-specific clinical mastitis in dairy cows. J. Dairy Sci. 97:2101-2117.

Chebel, R. C., J. E. P. Santos, J. P. Reynolds, R. L. A. Cerri, S. O. Juchem, and M. Overton. 2004. Factors affecting conception rate after artificial insemination and pregnancy loss in lactating dairy cows. Anim. Reprod. Sci. 84:239-255.

Cronin, J. G., M. L. Turner, L. Goetze, C. E. Bryant, and I. M. Sheldon. 2012. Toll-like receptor 4 and MYD88-dependent signaling mechanisms of the innate immune system are essential for the response to lipopolysaccharide by epithelial and stromal cells of the bovine endometrium. Biol. Reprod. 86:51.

Fourichon, C., H. Seegers, and X. Malher. 2000. Effect of disease on reproduction in the dairy cow: A meta-analysis. Theriogenology 53:1729-1759

Gröhn, Y. T., D. J. Wilson, R. N. González, J. A. Hertl, H. Schulte, G. Bennett, and Y. H. Schukken. 2004. Effect of pathogen-specific clinical mastitis on milk yield in dairy cows. J. Dairy Sci. $87: 3358-3374$.

Gustafsson, H., and U. Emanuelson. 2002. Characterisation of the repeat breeding syndrome in Swedish dairy cattle. Acta Vet. Scand. 43:115-125.

Hansen, P. J., P. Soto, and R. P. Natzke. 2004. Mastitis and fertility in cattle - Possible involvement of inflammation or immune activation in embryonic mortality. Am. J. Reprod. Immunol. 51:294301

Hassan, K. J., S. Samarasinghe, and M. G. Lopez-Benavides. 2009. Use of neural networks to detect minor and major pathogens that cause bovine mastitis. J. Dairy Sci. 92:1493-1499.

Herath, S., S. T. Lilly, D. P. Fischer, E. J. Williams, H. Dobson, C. E Bryant, and I. M. Sheldon. 2009. Bacterial lipopolysaccharide induces an endocrine switch from prostaglandin $\mathrm{F}_{2 \alpha}$ to prostaglandin $\mathrm{E}_{2}$ in bovine endometrium. Endocrinology 150:1912-1920.

Hertl, J. A., Y. T. Gröhn, J. D. G. Leach, D. Bar, G. J. Bennett, R. N. González, B. J. Rauch, F. Welcome, L. W. Tauer, and Y. H. Schukken. 2010. Effects of clinical mastitis caused by grampositive and gram-negative bacteria and other organisms on the probability of conception in New York State Holstein dairy cows. J. Dairy Sci. 93:1551-1560.

Hertl, J. A., Y. H. Schukken, F. L. Welcome, L. W. Tauer, and Y. T. Gröhn. 2014. Pathogen-specific effects on milk yield in repeated clinical mastitis episodes in Holstein dairy cows. J. Dairy Sci. 97:1465-1480.
Hockett, M. E., R. A. Almeida, N. R. Rohrbach, S. P. Oliver, H. H. Dowlen, and F. N. Schrick. 2005. Effects of induced clinical mastitis during preovulation on endocrine and follicular function. J. Dairy Sci. 88:2422-2431.

Huang, C., S. Tsuruta, J. K. Bertrand, I. Misztal, T. J. Lawlor, and J. S. Clay. 2008. Environmental effects on conception rates of Holsteins in New York and Georgia. J. Dairy Sci. 91:818-825.

Hudson, C. D., A. J. Bradley, J. E. Breen, and M. J. Green. 2012. Associations between udder health and reproductive performance in United Kingdom dairy cows. J. Dairy Sci. 95:3683-3697.

Huszenicza, G.. S. Jánosi, M. Kulcsár, P. Kóródi, J. Reiczigel, L. Kátai, A. R. Peters, and F. De. Rensis. 2005. Effects of clinical mastitis on ovarian function in post-partum dairy cows. Reprod. Domest. Anim. 40:199-204.

Lam, T. J. G. M., Y. H. Schukken, J. H. van Vliet, F. J. Grommers, M. J. M. Tielen, and A. Brand. 1997. Effect of natural infection with minor pathogens on susceptibility to natural infection with major pathogens in the bovine mammary gland. Am. J. Vet. Res. $58: 17-22$.

López-Gatius, F., P. Santolaria, J. Yániz, J. Rutllant, and M. LópezBéjar. 2002. Factors affecting pregnancy loss from gestation Day 38 to 90 in lactating dairy cows from a single herd. Theriogenology $57: 1251-1261$

Moore, D. A., J. S. Cullor, R. H. Bondurant, and W. M. Sischo. 1991 Preliminary field evidence for the association of clinical mastitis with altered interestrus intervals in dairy cattle. Theriogenology $36: 257-265$.

Moore, D. A., M. W. Overton, R. C. Chebel, M. L. Truscott, and R. H. BonDurant. 2005. Evaluation of factors that affect embryonic loss in dairy cattle. J. Am. Vet. Med. Assoc. 226:1112-1118.

Reyher, K. K., I. R. Dohoo, D. T. Scholl, and G. P. Keefe. 2012. Evaluation of minor pathogen intramammary infection, susceptibility parameters, and somatic cell counts on the development of new intramammary infections with major mastitis pathogens. J. Dairy Sci. 95:3766-3780.

Risco, C. A., G. A. Donovan, and J. Hernandez. 1999. Clinical mastitis associated with abortion in dairy cows. J. Dairy Sci. 82:16841689

Santos, J. E. P., R. L. A. Cerri, M. A. Ballou, G. E. Higginbotham, and J. H. Kirk. 2004. Effect of timing of first clinical mastitis occurrence on lactational and reproductive performance of Holstein dairy cows. Anim. Reprod. Sci. 80:31-45.

SAS Institute. 2009. SAS Help and Documentation. SAS version 9.2 SAS Institute Inc., Cary, NC.

Schukken, Y. H., M. Chuff, P. Moroni, A. Gurjar, C. Santisteban, F. Welcome, and R. Zadoks. 2012. The 'other' gram-negative bacteria in mastitis: Klebsiella, Serratia, and more. Vet. Clin. North Am. Food Anim. Pract. 28:239-256.

Williams, E. J., K. Sibley, A. N. Miller, E. A. Lane, J. Fishwick, D. M. Nash, S. Herath, G. C. England, H. Dobson, and I. M. Sheldon. 2008. The effect of Escherichia coli lipopolysaccharide and tumor necrosis factor alpha on ovarian function. Am. J. Reprod. Immunol. 60:462-473.

Wilson, D. J., Y. T. Gröhn, G. J. Bennett, R. N. González, Y. H. Schukken, and J. Spatz. 2008. Milk production change following clinical mastitis and reproductive performance compared among J5 vaccinated and control dairy cattle. J. Dairy Sci. 91:3869-3879. 